\title{
Evolution Of Direct Shipping Of Wine In The United States -- Economic, Legal And Political Considerations
}

Charles W. Ehart, D.P.A., Hodges University, USA

Donald A. Forrer, D.B.A., Hodges University, USA

\begin{abstract}
The study examines the effort of wine producers and others in the United States to permit direct shipping of wine to consumers bypassing the traditional three-tier system, where product typically flows from the supplier, to the wholesaler, to the retailer, and ultimately the consumer. The case study places an emphasis on the economic, legal and political issues that have been faced by state legislatures when considering proposals to permit direct shipping. The analysis will discuss the history and evolution of public policies and state laws in the past three decades and will focus on the Maryland experience.
\end{abstract}

Keywords: Wine; Alcohol; Direct Shipping; Public Policy

\section{INTRODUCTION}

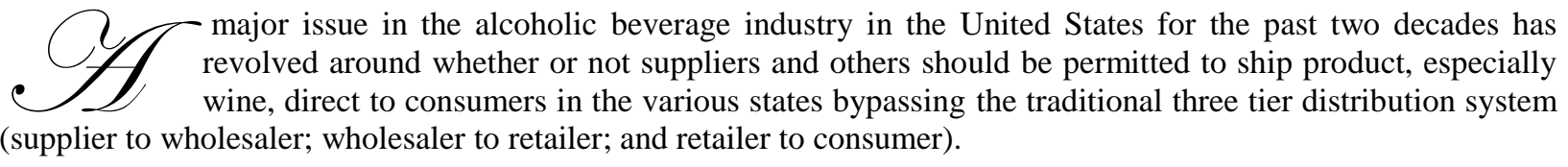

Many in the industry, particularly wineries in California, have argued that direct shipping was necessary for the economic viability of their industry. Consumers have argued that the supply of product in local retail stores is limited and they should be free to obtain product they want from any source. With the popularity of online shopping in recent years, both the producers and consumers have pushed harder for laws that would allow free access to wine via the internet.

Regulators historically opposed direct shipments for three distinct reasons:

1. The possibility that those under the legal age of 21 would purchase and/or receive alcohol products. (While wine is the main commodity for online sales, both distilled spirits and malt beverage products, popular with the 18-21 age group, have been known to be shipped direct to homes or even college campuses.)

2. Alcoholic beverages shipped direct to a consumer would avoid payment of state excise and sales taxes, particularly if the shipment was from another state.

3. The traditional three tier system, and all the controls inherent in it, would be bypassed. Additionally, wholesalers and retailers in states pay significant licensing fees and this would put them at a disadvantage with out of state shippers. These wholesalers and retailers are held accountable for paying the excise and sales taxes and for ensuring minors do not purchase or receive product.

This paper is a case study that looks at the economic, political and legal factors involved in this issue and how public and government opinion has evolved in the past two decades. The paper concentrates on the Maryland experience. 


\section{FEDERAL REGULATION OF ALCOHOLIC BEVERAGES}

Beverage alcohol is the only commodity to be the subject of two Amendments to the United States Constitution. The $18^{\text {th }}$ Amendment, ratified in 1919, was known as "Prohibition" and prohibited the manufacture, sale, and possession of alcoholic beverages. This prohibition was generally considered a failure and led to widespread disregard for the law, political corruption, and organized crime involvement in the illegal manufacture and distribution of alcohol products.

The $21^{\text {st }}$ Amendment, ratified in 1933, granted each state the exclusive right to regulate the manufacture, sale, distribution, and transportation of alcoholic beverages within its borders. Some states elected, in whole or in part, to stay "dry" meaning no alcohol would be manufactured or sold, and in some cases possessed, within a state or sub-division of a state. Today, "dry" jurisdictions still exist in parts of the United States. Most states elected to establish a licensing system, whereby private entities sold the product. These are known as license states and are the majority of states today. Other states decided to sell and control the product themselves. These are known are control states.

The federal government, however, continues to play a role in the regulation of alcoholic beverages, primarily through the Alcohol and Tobacco Tax and Trade Bureau (TTB). Many states continue to follow federal laws in the areas of labeling, advertising, and trade practices. Although there is no prohibition on direct wine shipping at the federal level, the Bureau of Alcohol, Tobacco and Firearms (BATF), predecessor to TTB for regulatory activities, has issued a number of industry notices on the subject.

At the urging of the National Conference of State Liquor Administrators (NCSLA), an Industry Circular was issued in 1996 (Number 96-3) and a Ruling in 2000 (Ruling 2000-1). These notices essentially stated that one of the conditions for maintaining a federal alcohol permit under the Federal Alcohol Administration Act (FAA) was compliance with the $21^{\text {st }}$ Amendment and therefore a violation of the Act could result in suspension or revocation of a federal basic permit. BATF stated that while it would not initiate action on its own, it would consider action if a complaint was filed by a state regulatory agency.

\section{MARYLAND REGULATION OF ALCOHOLIC BEVERAGES}

Since repeal of Prohibition in 1933, alcoholic beverages in Maryland have been regulated by the three tier system. Maryland, like most states, generally operates as a "license" system. However, it is somewhat unique in that it has authorized certain counties (sub-divisions) to operate their own dispensaries and sell product at the wholesale and/or retail level.

At the state level, statewide regulation and the collection of the excise taxes is the responsibility of the state comptroller, a statewide elected position. While the comptroller issues licenses and permits at the state level, each of the 24 political sub-divisions has its own liquor board, responsible for licensing and regulating the sale of alcohol at the retail level.

All laws pertaining to alcohol must be passed by the state legislature, even those that may only affect one or a few sub-divisions. The state may promulgate regulations to carry out the intent of the alcohol laws, contained in Article 2B of the Annotated Code of Maryland.

\section{ECONOMIC ISSUES}

There are a number of economic viewpoints to consider when looking at the direct shipping issue. These perspectives include:

1. Seller and suppliers of alcohol (in-state and out-of-state)

2. In state wholesalers and retailers

3. Consumers

4. Government units charged with collecting the excise and sales taxes 
Eyler (2003) believes that a distribution system that is allowed to act free of government intervention results in markets that are efficient by maximizing societal welfare. Repealing restrictive laws, according the Eyler, would increase consumer benefits and increase competition.

While the repeal of restrictive laws would benefit producers and suppliers who could directly sell their product to consumers, it would be a detriment to wholesalers and retailers in those states. These "middle tiers" of the traditional distribution network would be bypassed. They would have lost opportunity of sales and lost profit. Presumably consumers who purchase from direct shippers would purchase less from the traditional retailer.

According to Eyler (2003), market economics that begin with the concept of free trade leads to its best economic outcome and if public policy forces deviate from market driven equilibrium, this is detrimental to societal welfare. Most consumers who wish to engage in direct shipping activity would agree with this approach. Interestingly, price is not a key consideration for these consumers. They want to purchase specific brands and vintages of wines and generally do not care that they may cost more plus they have to pay shipping costs. For these consumers, economic considerations do not play a role in their purchases.

The final player to be examined in economic considerations is the government itself. One of the key reasons stated earlier for states initially opposing direct shipping is the fact that state excise taxes may be avoided as the direct shipper may not have a license or other connection with the destination state, and has no incentive or mechanism to pay the tax. The consumer likewise has no incentive to be concerned with taxes either, much the same as their approach to internet sales of other commodities.

Various economic and public interest factors affect the likelihood that a state adopts a change in direct shipping regulation. Riekof and Sykuta (2005) suggest that public and private sector economic considerations lie at the root of direct shipping regulations in the wine industry.

\section{LEGAL ISSUES}

As earlier indicated, there are no specific federal laws that prohibit direct shipping, although federal agencies have continued to support states' right to regulate alcoholic beverages pursuant to the 21 st Amendment. However, Congress and the Supreme Court have played a larger role in this issue.

In 2000, Congress passed the Twenty-First Amendment Enforcement Act. This Act gave the Attorney General in each state the power to bring a civil suit for injunctive relief against an out-of-state supplier who violates state alcohol laws (Foust, 2000). A successful action, according to the Act, depended upon whether the state could show by a preponderance of evidence that a state law was violated, and provide evidence that if an injunction were not issued, there would be a strong probability of irreparable injury, and provide further evidence supporting the probability on the merits of each individual case.

One of the most significant developments in the direct shipping controversy was the 2005 Supreme Court Granholm v. Heald decision that struck down discriminatory direct shipping statutes. After the Granholm decision, states with discriminatory laws on the books had to decide whether to prohibit all direct shipping or allow all direct shipping (Ohlhaussen and Luid, 2008). The Court, in the Granholm decision, also took aim at the state's tax collection argument suggesting that states could incorporate a tax remittance system as part of direct shipping licensing.

While Maryland did not discriminate (neither in-state or out-of-state producers could ship to consumers), many states did. Several states decided that rather than prohibit in-state direct shipping they would amend their law and allow direct shipping from out of state as well (Ohlhaussen and Luid, 2008). In some cases, they have allowed not only direct shipping to consumers but also to in-state retailers, bypassing wholesalers.

Throughout the direct shipping issue, there has been a conflict between the Commerce Clause (promoting free trade) and the 21st Amendment to the United States Constitution, under which states have enacted three tier laws. In the wake of Granholm, constitutional law on direct wine shipment is far from settled. Federal court decisions about direct wine shipment law have yielded inconsistent results (Direct Wine Shipping Report, 2010). 
In 2010, the "Comprehensive Alcohol Regulatory Effectiveness Act of 2010" (CARE) was introduced in the House of Representatives. The bill's stated purposes were: "(1) recognize that alcohol is different from other consumer products and that it should be regulated effectively by the States according to the laws thereof; and (2) reaffirm and protect the primary authority of States to regulate alcoholic beverages" (CARE Act, 2010).

The bill was supported by national wholesaler groups, included the National Beer Wholesalers Association and the Wine and Spirits Wholesalers of America, and was seen as a way to protect the three tier system. The belief was that if state laws regulating alcoholic beverages and the 21st Amendment were scrutinized under the Commerce Clause, that it was only a matter of time before the three tier system met its demise (Direct Wine Shipment Report, 2010).

The opponents, including the Wine Institute (California wineries), state that the CARE act "would allow states, at the urging of wholesalers, to eliminate direct shipping laws" (Direct Wine Shipment Report, 2010).

While the CARE Act failed to pass in 2010, it is likely to be resurrected in a future Congress.

\section{POLITICAL CONSIDERATIONS}

Whether in Congress or the various states, the legislative process is complicated. It would be naïve to ignore the politics involved in the legislative process. A legislative proposal can be introduced - and fail - multiple times before it eventually succeeds. Often, minor changes in law are made followed by more substantial changes in succeeding years or decades. In public policy this model is known as "incrementalism" (Dye, 2011).

The alcoholic beverage industry is a powerful player both in Congress and in state legislatures. They have lobbyists on the scene during the legislative sessions and they contribute significant amounts to political action committees (PACs) and individual elected officials within limits prescribed by law.

For many years, both the industry and government regulators were often on the same page on the direct shipping issue. Both believed strongly in the three tier system but sometimes for different reasons. Regulators initially opposed direct shipping to ensure the integrity of the system, to provide the best assurance that minors would not purchase or receive product, and to maintain all the other controls inherent in that system. The industry (wholesalers and retailers) believed in these reasons too but had other considerations.

While industry members felt that direct shipping of wine would result in some lost sales they had other concerns. It had been reasonably established that most direct shipping was wine to "connoisseurs" who made up a small percentage of the consumer population. The more significant reason was a legislative syndrome known as the "camel's nose under the tent". If direct shipping were permitted for rare and expensive wines, they argued, it would only be a matter of time before there was a demand to have any alcohol products shipped direct like other mainstream products. This was clearly seen as a threat to those in the middle tiers of the distribution system.

Initially, most states prohibited direct shipping. Later, some states passed reciprocity laws that allowed direct shipping to another state only if there was a similar law in that state. At first these were states, like California, that had a large number of wine producers. Some states were passive in their enforcement. Others, like Maryland, were more aggressive.

Over the years, however, pressure from consumer groups and both in-state and out-of-state wineries, saw a drastic relaxation of laws whereby the majority of states, by 2010, permitted direct shipping in one form or another. Industry groups, who previously opposed direct shipping, decided to make the best of the situation and began working with lawmakers and other industry members to craft legislation they could live with and still reasonably protect their interests.

As of 2010, 36 states and the District of Columbia allow direct shipping with a license or permit, one state permitted reciprocal shipments, and 13 states prohibited direct shipping (source: Direct Wine Shipment Report, 2010). 


\section{EVOLUTION OF DIRECT SHIPPING IN MARYLAND}

Direct shipping became an issue for regulators in the early 1990s in Maryland and most other states. There were two categories of shippers - those who had a permit to ship to wholesalers through legitimate channels (i.e. "nexus" with the state) and out-of-state producers with no connection to the state. While direct shipping to consumers was illegal in both cases, it was impractical to prosecute those without a permit located in another state.

In 1994, the Maryland Alcohol and Tobacco Tax Division issued Administrative Release (No. AB-1) to all wholesalers and out of state dealers calling attention to the new trend and reminding licensees that these activities could result in license or permit suspension, revocation, or monetary fines. Nevertheless, recognizing the potential for additional sales and believing there would be little or no enforcement from regulatory authorities, some out of state wineries with licenses to do business in Maryland (through the three tier system) began taking orders from consumers in Maryland.

In an effort to curtail these activities, the Alcohol and Tobacco Tax Division engaged in several "sting" operations, having employees order a case of wine and having it shipped to the State Treasury Building. A number of wineries were charged with selling contraband product and paid significant fines. One major California winery, Kendall Jackson, paid \$35,000 in 1997 (Maryland Alcohol and Tobacco Tax Bulletin AB-15).

After the sting operations, those with licenses or permits avoided direct shipping to Maryland consumers and concentrated on states with little or no enforcement. The problem with unlicensed entities, with no nexus in the state, continued unabated.

The Maryland General Assembly recognized this ongoing problem and was particularly concerned with the possibility of minors receiving product. In 1999, H.B. 278, supported by the state comptroller, was enacted which made it a felony "for anyone engaged in the business of selling or distributing alcoholic beverages in or from another state to ship, cause to be shipped, or deliver alcoholic beverages to persons in Maryland who do not hold the proper class of license or permit". This law applied not only to the shipper (wine producer) but also to common carrier shippers, like UPS and Federal Express.

In the next several years, several attempts were made in the General Assembly to enact laws permitting direct shipping. These attempts were opposed by the state comptroller and the powerful alcoholic beverage industry in Maryland. One segment of the local industry, however, supported these efforts. Maryland wineries were also prohibited from direct shipping to consumers (the Granholm decision would not permit allowing direct shipping by in-state wineries while prohibiting it from out-of-state wineries). All these legislative efforts failed.

The first post-Granholm decision effort to permit direct shipping was introduced in 2006. Subsequent bills followed in 2008, 2009, and 2010 (Direct Wine Shipment Report, 2010). A significant event during this period was the election of a new state comptroller in 2006. The previous comptrollers had taken a proactive position against any legislation to permit direct shipping. The new comptroller was more sympathetic to consumers who wanted to receive wine direct and had supported some direct shipping efforts during his tenure as a delegate in the General Assembly. While he did not take a proactive position for direct shipping legislation and remained neutral, this removed a previous major obstacle to passage.

In the 2011 General Assembly session, H.B. 1175 was passed and signed by the governor (Maryland Field Enforcement Division Bulletin AB-42). This bill created a direct wine shipper's permit for both in-state and out-ofstate wineries. Under the law, a permit holder can ship up to 18 cases of wine a year to a single Maryland address. The new law also created a quarterly tax return for payment of excise and sales taxes and requires a recipient signature of a person 21 years or older.

There are several reasons for how Maryland went from one of the most restrictive states to one of the many states that permitted direct shipping. They are: (1) the national trend where most states now allow direct shipping in one form or another; (2) the growing political influence of Maryland wineries; (3) the muted opposition of other segments of the Maryland alcohol industry; (4) the influence of the local media who supported the legislative and 
published pro-shipping editorials; and (5) a new state comptroller who did not oppose and tacitly endorsed the legislation.

\section{CONCLUSION}

The direct shipping debacle in the United States is a prime example and case study of "incrementalism" in the establishment of public policy. Twenty years ago, this activity was not envisioned in view of the $21^{\text {st }}$ Amendment, the three tier system of distribution, and the powerful alcoholic beverage lobby in the states. However, economic forces, the Granholm decision, public opinion, and the media have joined forces to minimize opposition to direct shipping laws. Clearly, political forces still exist but elected officials have demonstrated a need to balance regulatory concerns with public interests and demands.

\section{AUTHOR INFORMATION}

Dr. Charles W. Ehart is an Associate Professor of Public Administration for Hodges University and has taught graduate level courses in public administration and management since 1993. He also does work as a consultant in management and alcohol regulation. Dr. Ehart retired in 2003 as an Assistant State Comptroller with the State of Maryland, and served as the Director of the Alcohol and Tobacco Tax Division. In this capacity he was responsible for regulating the alcoholic beverages and tobacco industries in the state and collecting the excise tax on distilled spirits, beer, wine, cigarettes, and other tobacco products. He is a past president of the National Conference of State Liquor Administrators and former chairman of the Tobacco Tax Section of the Federation of Tax Administrators. E-mail: cehart@ hodges.edu. Corresponding author.

Dr. Donald A. Forrer serves as Professor at Hodges University in Naples Florida. Dr. Forrer serves as a consultant to government and small businesses. Don serves as the President of his consulting firm "Cybernetic Concepts". The firm specializes in water and sewer rates and charges. He is a member of the Rates and Charges committee of the American Water Works Association (AWWA). This prestigious committee writes the M1 manual that establishes water and wastewater rates/charges for the industry. Dr. Forrer's area of research is utility economics where he has presented and published numerous papers. Dr. Forrer has also authored two books. E-mail: dforrer@hodges.edu.

\section{REFERENCES}

1. ATF Ruling 2000-1 (2000). Direct shipment sales of alcohol beverages. United States Department of the Treasury, Bureau of Alcohol, Tobacco and Firearms.

2. Bulletin AB-1 (1994). Comptroller of the Treasury, Alcohol and Tobacco Tax Division.

3. Bulletin AB-15 (1997). Comptroller of Maryland, Alcohol and Tobacco Tax Division.

4. Bulletin AB-26 (1999). Comptroller of Maryland, Alcohol and Tobacco Tax Division.

5. Bulletin AB-42 (2011). Comptroller of Maryland, Field Enforcement Division.

6. Direct Wine Shipment Report (2010). Submitted to the Maryland General Assembly by the Comptroller of Maryland. December 31, 2010.

7. Dye, Thomas R. (2011). Understanding Public Policy (2011); 13th edition. ISBN: 978-0-205-75742-8.

8. $\quad$ Eighteenth Amendment to the United States Constitution (1919).

9. Eyler, Robert (2003). Direct shipping laws, wine and societal welfare. International Journal of Wine Marketing. Vol. 15, Issue 2, page 25.

10. Foust, John (2000). State power to regulate alcohol under the twenty-first amendment: the constitutional implications of the twenty-first amendment enforcement act. Boston Law College Review. 41 B.C.L. Rev. 659, pgs. 668-670.

11. Granholm v. Heald, 544 U.S. 460, 6 (2005). United States Supreme Court.

12. H. R. 5034 (2010). "Comprehensive Alcohol Regulatory Effectiveness (CARE) Act of 2010. United States Congress.

13. House Bill 278 (1999). Maryland General Assembly. Direct Shipments of Alcohol - Felony.

14. House Bill 1175 (2011). Maryland General Assembly. Alcohol Beverages - Direct Wine Shipment. 
15. Industry Circular, Number 96-3 (1996). Direct shipment sales of alcoholic beverages. United States Department of the Treasury, Bureau of Alcohol, Tobacco and Firearms.

16. Ohlhausen, Maureen K. and Luib, Gregory P. (2008). Moving sideways: Post-Granholm developments in wine direct shipping and their implications on competition. Antitrust Law Journal. 75 Antitrust L. J. 505.

17. Riekhof, Gina M. and Sykuta, Michael E (2005). Politics, economics and the regulation of direct interstate shipping in the wine industry. American Journal of Agricultural Economics. Vol. 87, Issue 2, pgs. 439452.

18. The Twenty-First Amendment Enforcement Act (2000). United States Congress. 


\section{NOTES}

